\title{
Early experience with sacubitril/valsartan at University Hospital Centre Zagreb, Department of Cardiovascular Diseases
}

\section{Saša Pavasović*, Ana Reschner, Marijan Pašalić, Davor Miličić}

University of Zagreb School of Medicine, University Hospital Centre Zagreb, Zagreb,

Croatia
KEYWORDS: heart failure, sacubitril/valsartan, NT-proBNP, left ventricular ejection fraction. CITATION: Cardiol Croat. 2017;12(9-10):361. | https://doi.org/10.15836/ccar2017.361

*ADDRESS FOR CORRESPONDENCE: Saša Pavasović, Klinički bolnički centar Zagreb, Kišpatićeva 12, HR-10000 Zagreb, Croatia. / Phone: +385-1-2367-467 / E-mail: pavasovic.sasa@gmail.com

ORCID: Saša Pavasović, http://orcid.org/0000-0002-3705-0226 • Ana Reschner, http://orcid.org/0000-0002-6723-6822 Marijan Pašalić, http://orcid.org/0000-0002-3197-2190 • Davor Miličić, http://orcid.org/0000-0001-9101-1570

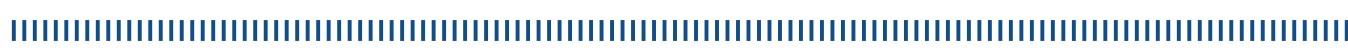

Background: The ARB/neprilysin inhibitor sacubitril/valsartan reduced cardiovascular morbidity and mortality compared with enalapril in patients with HF and reduced left ventricular ejection fraction (LVEF) according to the PARADIGM-HF trial., ${ }^{1,2}$ The aim was to analyze several clinical parameters in patients with chronic systolic heart failure (CHF) after sacubitril/valsartan was introduced instead of ACEI/ARB.

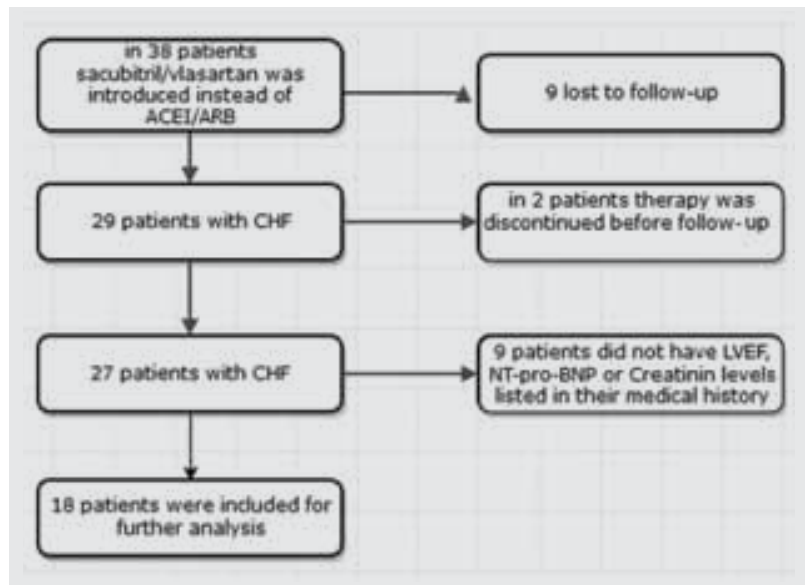

FIGURE 1. Inclusion/exclusion criteria.

Patients and Methods: We have analyzed the medical history of 38 consecutive patients treated for HF with reduced ejection fraction hospitalized at the University Hospital Center Zagreb, Department of Cardiovascular Diseases, between October 2016 and March 2017., both before and 3 months after the introduction of sacubitril/valsartan therapy (Figure 1). Prior to the introduction of sacubitril/valsartan, all examined patients have been on therapy with ACE inhibitors/ARBs at least three months. LVEF, NT-proBNP and creatinine were analyzed with the Wilcoxon signed rank test to check for statistical significance before and 3 months after the introduction of sacubitril/valsartan.

Results: Before the initiation of sacubitril/valsartan, these patients had a mean LVEF of $24 \%$. After three months of therapy with sacubitril/valsartan, they had an increase of their average LVEF by $20 \%$ to $29 \%$, which has been shown to be statistically significant with $\mathrm{P}=0.019$. Also, accompanying this change, in the same group of patients we observed a decrease in the average NT-proBNP by $47 \%$ (before sacubitril/valsartan therapy mean value $3335 \mathrm{pg} / \mathrm{ml}$ to $1593 \mathrm{pg} / \mathrm{ml}$ after three months of therapy) which is a statistically significant decrease with $\mathrm{P}=0.031$. We found no significant changes in NYHA category nor in the creatinine values (Table $\mathbf{1}$ ).

Conclusion: In our patients with CHF after the introduction of sacubitril/valsartan instead of ACI/ARB there was a significant increase in LVEF and a drop of NT-proBNP in the period of 3 months after the introduction of sacubitril/valsartan.

TABLE 1. Left ventricular ejection fraction, NT-pro-BNP and creatinine values before introduction of sacubitril/valsartan and 3 months after.

RECEIVED:

September 24, 2017

ACCEPTED:

September 26, 2017

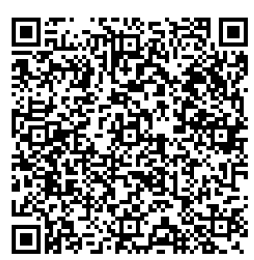

\begin{tabular}{lcccccccc}
\multicolumn{3}{c}{ Baseline } & & & \multicolumn{3}{c}{ 3 months follow-up } \\
\hline & Min. & Max. & Mean & Min. & Max. & Mean & P-value \\
\hline Left ventricular ejection fraction $(\%)$ & 10 & 35 & $24( \pm 6.5)$ & 20 & 42 & $29( \pm 5.6)$ & $0.019 *$ \\
\hline NT-proBNP $(\mathrm{pg} / \mathrm{ml})$ & $\mathbf{3 2 6 . 3}$ & 14491 & $4143( \pm 4418)$ & 214 & 6785 & $1926( \pm 1815)$ & $0.031 *$ \\
\hline Creatinine $(\mathrm{umol} / \mathrm{ml})$ & 58 & 245 & $114.2( \pm 40)$ & 74 & 197 & $123,3( \pm 35.8)$ & 0.126 \\
\hline
\end{tabular}

LITERATURE IIIIIIIIIIIIIIIIIIIIIIIIIIIIIIIIIIIIIIIIIIIIIIIIIIIIIIIIIIIIIIIIIIIIIIIIIIIIIIIIIIIIIIIIIIIIIIIIII

1. Packer M, McMurray JJ, Desai AS, Gong J, Lefkowitz MP, Rizkala AR, et al; PARADIGM-HF Investigators and Coordinators. Angiotensin receptor neprilysin inhibition compared with enalapril on the risk of clinical progression in surviving patients with heart failure. Circulation. 2015 Jan 6;131(1):54-61. https://doi.org/10.1161/CIRCULATIONAHA.114.013748

2. Solomon SD, Claggett B, Desai AS, Packer M, Zile M, Swedberg K, et al. Influence of Ejection Fraction on Outcomes and Efficacy of Sacubitril/Valsar$\tan$ (LCZ696) in Heart Failure with Reduced Ejection Fraction: The Prospective Comparison of ARNI with ACEI to Determine Impact on Global Mortality and Morbidity in Heart Failure (PARADIGM-HF) Trial. Circ Heart Fail. 2016 Mar;9(3):e002744. https://doi.org/10.1161/CIRCHEARTFAILURE.115.002744 